\title{
A Review of Contract Awards to Lowest Bidder in Indian Construction Projects via Case Based Approach
}

\author{
Shumank Deep, Deepak Singh, Syed Aqeel Ahmad \\ Department of Civil Engineering, Integral University, Lucknow, India \\ Email: shumank2012@gmail.com,deepakchaudhary8899@gmail.com, syedaqeelahmad@gmail.com
}

How to cite this paper: Deep, S., Singh, D. and Ahmad, S.A. (2017) A Review of Contract Awards to Lowest Bidder in Indian Construction Projects via Case Based Approach. Open Journal of Business and Management, 5, 159-168.

http://dx.doi.org/10.4236/ojbm.2017.51015

Received: December 23, 2016

Accepted: January 14, 2017

Published: January 17, 2017

Copyright $\odot 2017$ by authors and Scientific Research Publishing Inc. This work is licensed under the Creative Commons Attribution International License (CC BY 4.0).

http://creativecommons.org/licenses/by/4.0/

\begin{abstract}
Indian construction especially public sector organisations and government department mostly depends on lowest financial bidder for award of contracts. At some point time of these projects, it has become a common scenario that there is a schedule delay resulting in extension of time. So it can be mentioned that modern contract handling procedures require an overhauling. The study presents a case-based approach, in which authors have studied different projects that have been awarded on basis of financial criterion. Ultimately conclusions have been drawn by comparing efficiency of contractor with progress, ratio of bid and project cost and other factors.
\end{abstract}

\section{Keywords}

Contracts, Project Management, Tendering, Bidding, Contractor Efficiency, Construction Disputes

\section{Introduction}

Indian construction industry has played a vital role in growth for the Indian economy for over five decades and is the primary input for the socio-economic development of the country [1]. Increasing complexity in design and the involvement of numerous stakeholders in modern construction projects are a huge challenge for both clients and contractors to meet criterion of skills and capabilities required to successfully deliver a project at the bidding stage. Selection of an inappropriate contractor for the job increases the chance of dispute and dissatisfaction amongst stakeholders [2]. Consequently, the outcomes potentially cause huge financial losses resulting in poor business practices or bankruptcy to contractors [3] [4], while pre-qualification of contractors still remains the most fascinating topic of research [5] [6] [7] [8]. The criteria for prequalification in relation to the contractor's ability to meet the client's requirements and achieve success in projects are still a topic for investigation [9] [10]. Contrastingly, the 
lowest bid price is a highly weighted criterion, yet it is a prime cause of problem for selection of contractors in most works [11] [12]. Growth of public-private partnerships (PPP) in many countries including Australia, India etc. has provided an impetus to criticism of contractors' capacity to successfully deliver projects [13]. The increasing focus on the success dynamics (such as the value for money) of PPP projects requires not only a competitive price but also the unique contractor's capability in delivering state-of-the-art facilities and optimal operational performance over the project life cycle [14] [15] [16].

\section{Bidding Practices and Awards}

Bid and Procurement issues are widely related to the construction industry and its participants, in order to improve procurement of construction it is necessary for stakeholder to concentrate on bidding process [17]. Bid Awards are commonly done in Indian construction industry are generally based on financial criterion i.e. Lowest bidder is allowed to work. Achieving a value-based procurement approach is a huge challenge, particularly for the Indian public sector which depend majorly on lowest bid award system. In the current scenario it is observed that organizations submit low price tenders to win a project. Award of work on financial basis in current scenario leads to inferior quality of work [18]. Also sometimes leads to arbitration which further delays the schedule thereby causing increase in costs due to price escalations.

Currently, the public sector procurement of construction in India is based on the lowest bid award system popularly known as L1 type bidding. Practice of awarding contracts to a lowest bidder was established to ensure lowest cost for completing a project. In public construction works, this practice is almost universally accepted since it not only [19] ensures a low price but also provides a way to avoid fraud and corruption [20]. Moreover, the traditional approach tends to promote more adversarial relationships rather than cooperation or coordination among the contractor, the designer and the client, and client generally faces increased exposure to contractor claims over design and constructability issues [21].

The paper aims at analyzing the current status of Bid and Procurement Strategies in the construction industry of India. Most common method of awarding the contract as per government of India recommendation is the Least Responsive Bidder or Price Based method, which has inherent flaws of high competition and minimum performance. These incompetent practices pose constraints like [22]:

- Schedule delays

- Increase in total cost of the project, resulting in bankruptcy of companies

- Poor construction quality

- Serious question on public safety

- Overall project failure

Under this low-bid system, contractors submit bids based on plans and specifications prepared by the public agency or a consulting firm hired by the agency, except in case of low priced works, the contractor submitting the lowest responsive bid is awarded the contract. Generally, experience levels of the contractor, quality issues, and other criteria are not taken into consideration in awarding these contracts. 
The criteria applied for bid evaluation should reflect the client's objectives. The criteria for selecting the successful bidder are then that bid which tend to profit maximization. Thus author proposed that bidders should submit a schedule of the payments they expect during the contract [23]. Low initial funding of the project by the contractor, delay in procurement of materials, machineries and workforces are also the major factors identified as causes of delays during the construction phase in various projects [24].

\section{Legal Aspects}

Government of India has made it mandatory to have of competitive bidding for construction projects. This requires public organizations to award such contracts to the "lowest responsive bidder". The word "responsive" is inserted to require that a successful bid must also be adequately responding to the requirements of the project as specified. While it is not too difficult to determine whether a bid is responsive because responsiveness is evaluated based on the documents submitted by contractors, it takes considerable amount of time and effort to ascertain whether a bid is responsible. "Responsible" generally refers to the apparent low bidder's quality, fitness, and capacity to perform the proposed work satisfactorily. "Responsible" means more than simply financially responsible. The bidder must also have the requisite judgment, skill, ability, and integrity to perform the contract according to its terms [20].

Primarily, short duration of time available between a bid opening and the award of the bid. Secondly, the law allows public organizations to reject any or all the bids, the rejection cannot be done arbitrarily or in bad faith [23]. For these reasons, the decision to reject a low bid on the ground that the bidder was not responsible enough depends on the discretion of the client. In most cases some degree of subjectivity gets involved in the process of determining whether a particular bidder is responsible. As a consequence, these kinds of rejections frequently lead to litigations. In order to avoid such stereotypes, many organizations consider responsiveness of the bid before making award decisions. Some organizations use a stringent and specific set of prequalification procedures.

\section{Essential Elements of a Valid Contract}

Section 10 of the Indian Contract Act, 1872 provides that "all agreements are contracts if they are made by the free consent of parties competent to contract, for a lawful consideration and with a lawful object, and are not here by expressly declared to be void". The essential elements of a valid contract are:

- An offer or proposal by one party and acceptance of that offer by another party resulting in an agreement-consensus-ad-idem.

- An intention to create legal relations or an intent to have legal consequences.

- The agreement is supported by lawful consideration.

- The parties to contract are legally capable of contracting.

- Genuine consent between parties.

- The object and consideration of the contract is legal and is not opposed to public policy. 
- The terms of the contract are certain.

- The agreement is capable of being performed.

Therefore, to form a valid contract there must be (1) an agreement, (2) based on the genuine consent of the parties, (3) supported by consideration, (4) made for a lawful object, and (5) between the competent parties [25].

Least bid awarding procedure has been widely accepted in many countries for decades. However, allowing projects to be awarded based on the least price has become one of the major sources of construction projects failures. Delays in meeting deadline, escalation of the final project cost due to inflation, tendency to compromise quality, and adversarial relationship among contracting parties are the major drawbacks associated with responsive low-bid award procedure [26]. European Union introduced a legislation to allow public sector organisations option of awarding a construction contract by applying either traditional low bid or the Economically Most Advantageous Tender (EMAT). This aided public sector clients to reduce their exposure to some of adverse effects of extremely low tenders (ALT), including: poor quality of work due to reduced construction cost [27]; and Predatory pricing and unfair competition that disturbs the market, negatively affecting other participants [28].

\section{Research Methodology and Data Interpretation}

Based on conclusions drawn from literature available and information obtained through right to information act 2005 separate data sheet was developed to collect information from public sector organization and from consultants who are administering public owned construction projects. Twenty one Government of State of Uttar Pradesh, India owned construction projects awarded during 2011-2014 on basis of least bidder bid awarding system were investigated. In the our efforts to collect the details of projects, it was possible to obtain the detailed project reports for completed projects from the Government departments (10 projects) through applications under Right to Information Act, 2005 and from consultants working on outof11projectsunderthe survey.

Major data collection including project cost and extension of time given if any were obtained for all projects under the survey. Moreover, status of the project in relation to the planned schedule and the actual progress were recorded and summarized in Table 1. The financial summary of all the projects investigated is mentioned in Table 2.

The efficiency of projects under the study, with respect to their progress compared to the schedule/time elapsed, ranges from $41.67 \%$ to $147.78 \%$. Only $28.57 \%$ (6 projects) under the survey have efficiency greater than $80 \%$. Most projects, $52.38 \%$ ( 11 projects) have achieved only $20 \%$ to $50 \%$ of their schedule. $23.81 \%$ ( 5 projects) have found attaining about $50 \%$ to $80 \%$ of the approved schedule. The remaining $23.81 \%$ (5 projects) have the best progress from their schedule, achieved $100 \%$ with an efficiency ranged between $81 \%$ - 93\%. Figure 1 shows efficiency of work in different projects. From Figure 2 it can be easily observed that an increase in duration due to a possible extension in schedule could result in a decreased efficiency of contractor, Figure 3 shows a comparison of efficiency of lowest bidder to ratio of winner's offer to average bidder's offer. Though it could be impractical to compare financial performance with on field execution but still Figure 3 has brought out that efficiency of contractor is low. 


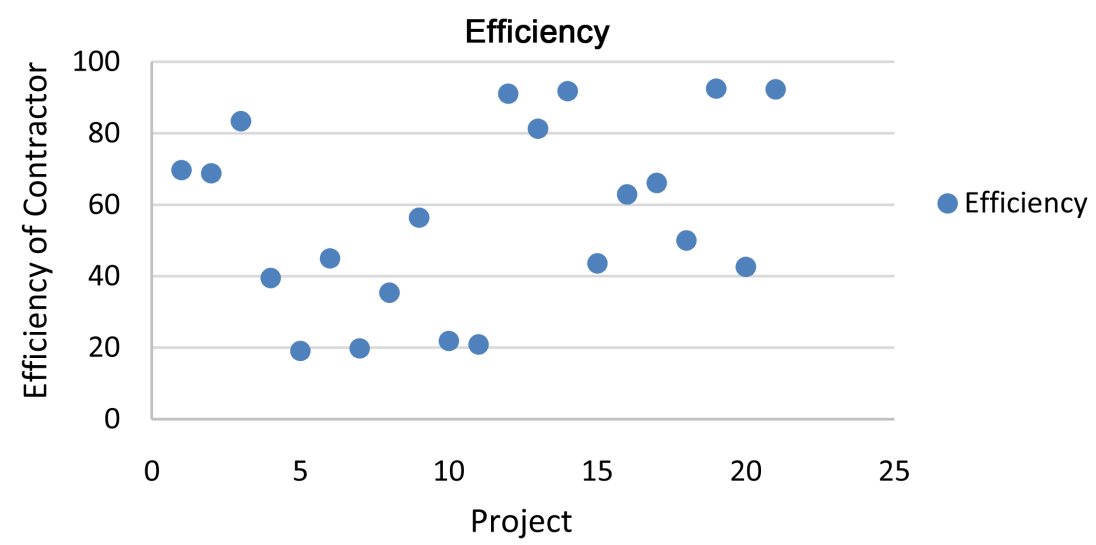

Figure 1. Efficiency of projects.

Table 1. Summary of work progress.

\begin{tabular}{|c|c|c|c|}
\hline Projects & Duration (\%) & Task Completed (\%) & Efficiency (\%) \\
\hline Pr-1 & 111.11 & 77.42 & 69.7 \\
\hline Pr-2 & 82.22 & 56.57 & 68.8 \\
\hline Pr-3 & 86.67 & 72.25 & 83.4 \\
\hline Pr-4 & 95.83 & 37.85 & 39.5 \\
\hline Pr-5 & 135.83 & 25.93 & 19.1 \\
\hline Pr-6 & 126.67 & 56.98 & 45.0 \\
\hline $\operatorname{Pr}-7$ & 147.78 & 29.3 & 19.8 \\
\hline $\operatorname{Pr}-8$ & 138.89 & 49.2 & 35.4 \\
\hline Pr-9 & 79.72 & 45 & 56.4 \\
\hline $\operatorname{Pr}-10$ & 136.94 & 30 & 21.9 \\
\hline $\operatorname{Pr}-11$ & 132.50 & 27.68 & 20.9 \\
\hline $\operatorname{Pr}-12$ & 109.72 & 100 & 91.1 \\
\hline Pr-13 & 123.06 & 100 & 81.3 \\
\hline Pr-14 & 108.89 & 100 & 91.8 \\
\hline $\operatorname{Pr}-15$ & 78.06 & 34 & 43.6 \\
\hline $\operatorname{Pr}-16$ & 83.33 & 52.42 & 62.9 \\
\hline $\operatorname{Pr}-17$ & 55.56 & 36.74 & 66.1 \\
\hline $\operatorname{Pr}-18$ & 41.67 & 20.85 & 50.0 \\
\hline $\operatorname{Pr}-19$ & 108.06 & 100 & 92.5 \\
\hline $\operatorname{Pr}-20$ & 108.89 & 46.38 & 42.6 \\
\hline Pr-21 & 108.33 & 100 & 92.3 \\
\hline
\end{tabular}

${ }^{*}$ When the percentage of time elapse disgreater than $100 \%$, percentage of time elapse distaken as percentage of Duration of work planned. 


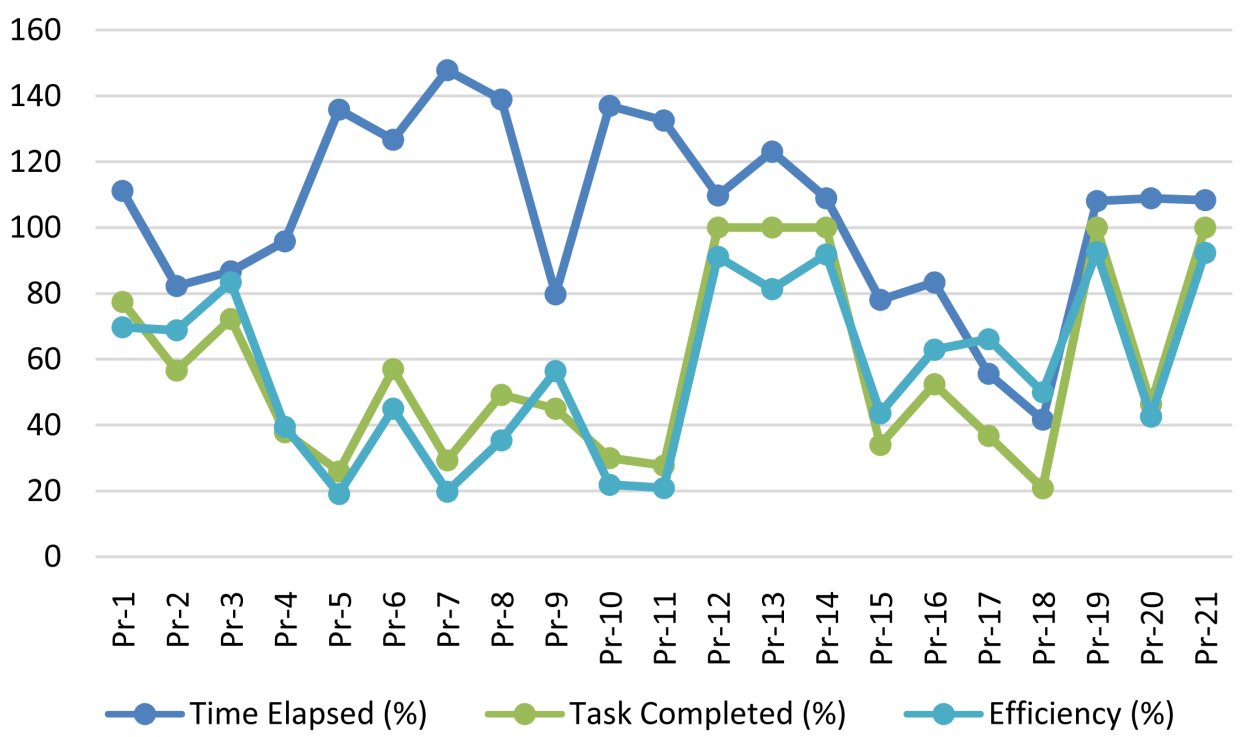

Figure 2. Comparison of efficiency, task status and time elapsed.

Table 2. Summary of financial offers (obtained through applications made via RTI Act, 2005).

\begin{tabular}{|c|c|c|c|c|c|}
\hline Projects & $\begin{array}{c}\text { Average of bidders' } \\
\text { Offer (INR)(A) }\end{array}$ & $\begin{array}{l}\text { Project Cost } \\
\text { (INR) (B) }\end{array}$ & $\begin{array}{l}\text { Winner's offer } \\
\text { (INR) (C) }\end{array}$ & $\begin{array}{l}\mathrm{C} / \mathrm{A} \\
(\%)\end{array}$ & $\begin{array}{l}\mathrm{C} / \mathrm{B} \\
(\%)\end{array}$ \\
\hline Pr-1 & $578,955,819.50$ & $600,000,000.00$ & $541,718,515.00$ & 93.6 & 90.29 \\
\hline Pr-2 & $560,045,576.00$ & $652,018,837.12$ & $537,524,143.00$ & 96.0 & 82.44 \\
\hline Pr-3 & $148,558,236.00$ & $151,311,616.51$ & $136,120,676.00$ & 91.6 & 89.96 \\
\hline $\operatorname{Pr}-4$ & $401,717,221.75$ & $435,735,213.47$ & $372,420,036.00$ & 92.7 & 85.47 \\
\hline Pr-5 & $694,344,982.00$ & $729,457,990.25$ & $617,731,977.00$ & 89.0 & 84.68 \\
\hline Pr-6 & $552,977,822.33$ & $595,512,890.96$ & $545,262,748.00$ & 98.6 & 91.56 \\
\hline Pr-7 & $319,475,425.00$ & $340,769,907.69$ & $309,755,259.00$ & 97.0 & 90.90 \\
\hline Pr-8 & $605,285,964.20$ & $623,598,090.96$ & $546,964,937.00$ & 90.4 & 87.71 \\
\hline Pr-9 & $537,451,403.80$ & $578,633,246.35$ & $502,877,507.00$ & 93.6 & 86.91 \\
\hline Pr- 10 & $579,256,642.25$ & $698,333,424.59$ & $453,990,619.00$ & 78.4 & 65.01 \\
\hline $\operatorname{Pr}-11$ & $9,864,289.75$ & $10,574,375.56$ & $7,478,718.00$ & 75.8 & 70.72 \\
\hline $\operatorname{Pr}-12$ & $18,989,253.50$ & $22,574,375.56$ & $18,817,893.00$ & 99.1 & 83.36 \\
\hline $\operatorname{Pr}-13$ & $3,374,055.75$ & $5,566,789.37$ & $2,938,827.00$ & 87.1 & 52.79 \\
\hline Pr-14 & $8,276,067.00$ & $9,000,000.00$ & $5,382,798.00$ & 65.0 & 59.81 \\
\hline Pr-15 & $88,474,895.67$ & $90,000,000.00$ & $73,470,443.00$ & 83.0 & 81.63 \\
\hline $\operatorname{Pr}-16$ & $22,211,877.25$ & $25,000,000.00$ & $18,938,435.00$ & 85.3 & 75.75 \\
\hline Pr-17 & $51,589,099.00$ & $52,000,000.00$ & $41,732,546.00$ & 80.9 & 80.25 \\
\hline Pr-18 & $65,087,310.20$ & $69,000,000.00$ & $54,024,082.00$ & 83.0 & 78.30 \\
\hline $\operatorname{Pr}-19$ & $33,185,996.00$ & $35,000,000.00$ & $32,183,445.00$ & 97.0 & 91.95 \\
\hline Pr-20 & $16,047,961.00$ & $19,000,000.00$ & $15,047,356.00$ & 93.8 & 79.20 \\
\hline $\operatorname{Pr}-21$ & $11,689,464.95$ & $14,000,000.00$ & $10,588,564.95$ & 90.6 & 75.63 \\
\hline
\end{tabular}


Though it is difficult to reach on a definite relationship between the progress of works and the ratio of winner's bid to the engineers estimate shown in Figure 4, but there is a tendency of decrease in efficiency as the ratio increases. The basic reason, from our observation and through interaction with experts, is due to the erroneous estimation of project cost. In government departments though estimation are made using proper methodologies but market escalation is not taken into account and even a sharp rise in inflation leads to decrease in efficiency. Also as evident from Figure 5, and interpretation time taken in completion of projects is mostly above the estimates deadline for project completion. Hence due to extension in schedule there is a decrease in efficiency.

\section{Conclusion}

The method of procurement of construction works has a significant role in the successful completion of the project. In this research, the performance of public owned

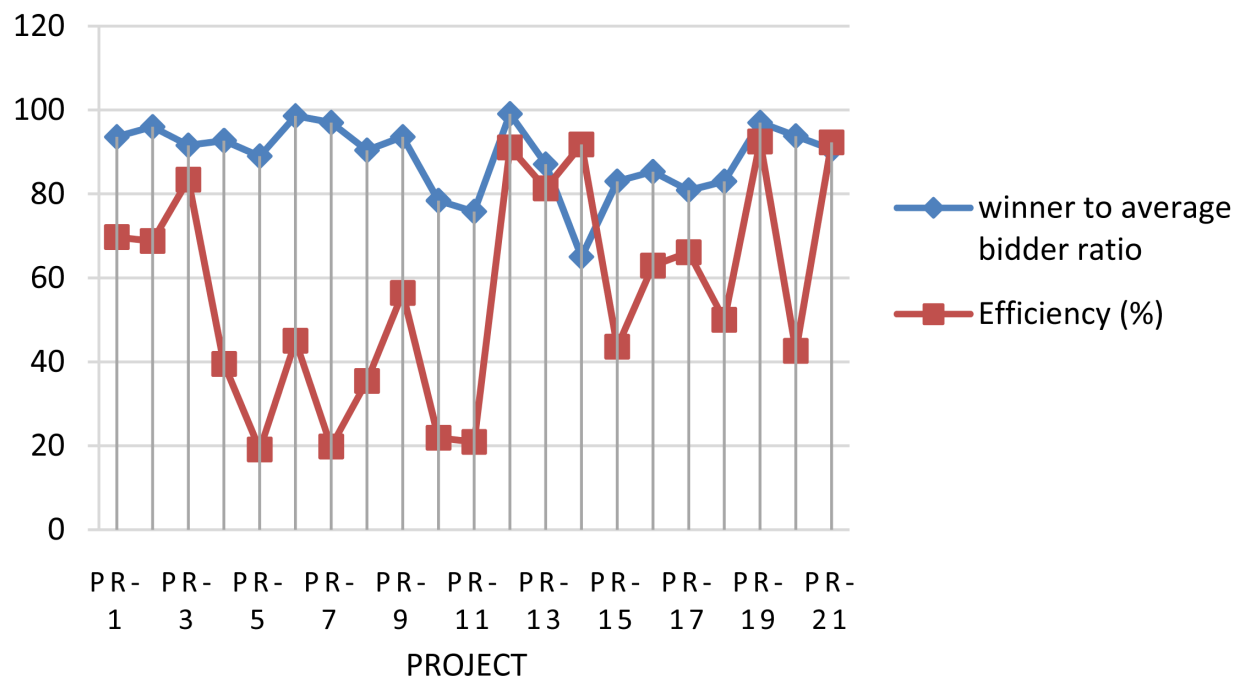

Figure 3. Relationship between efficiency and ratio of lowest bid to the average offer.

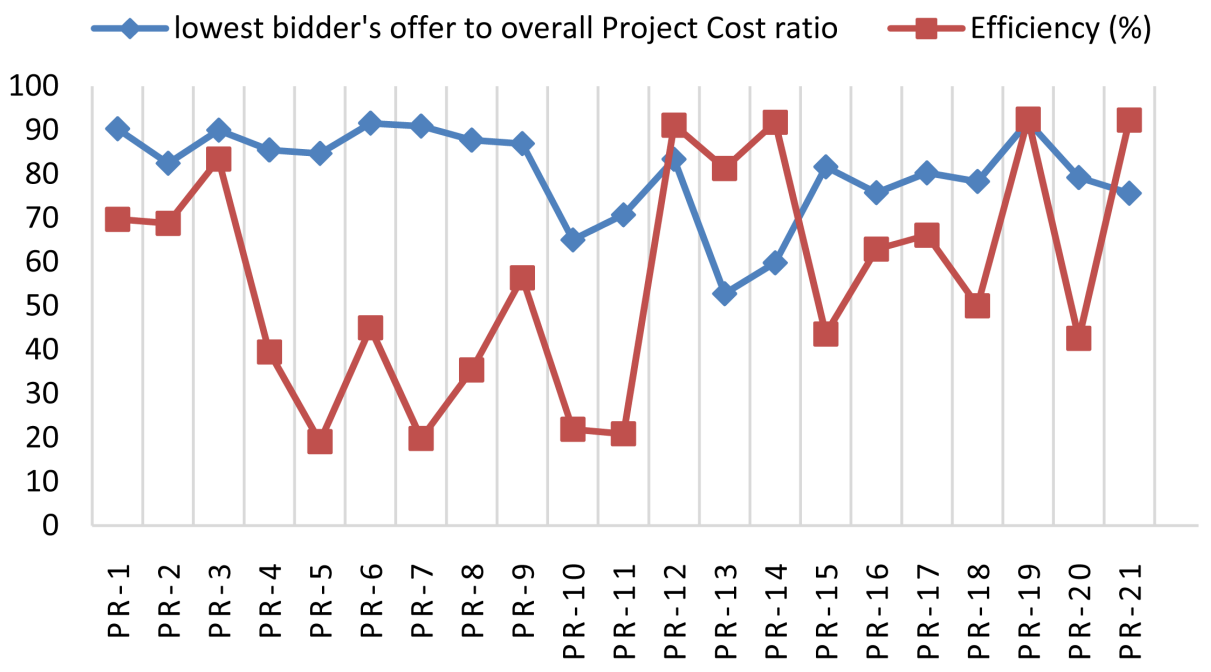

Figure 4. Relationship between efficiency and ratio of lowest bid to project cost. 


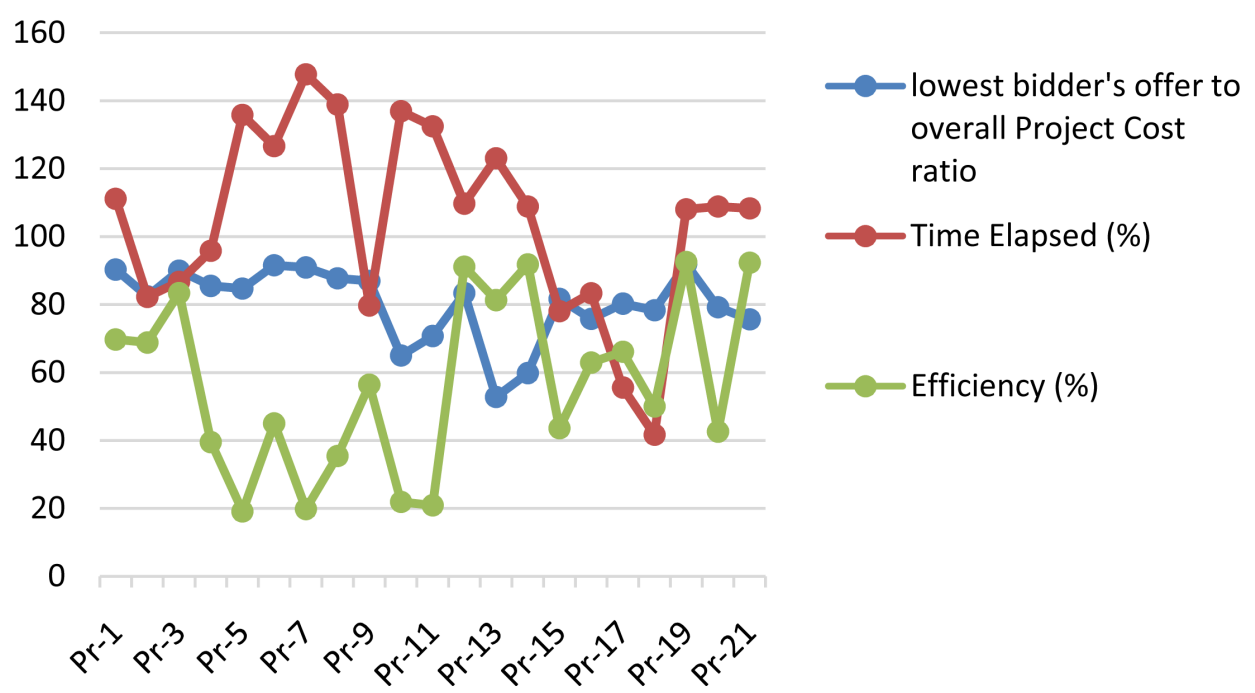

Figure 5. Relationship between efficiency, ratio of lowest bid to project cost and percentage of time elapsed.

construction projects awarded on the least bidder bid evaluation and contract award system was assessed. In addition, the researcher has tried to investigate opinions of construction professionals from private and public organizations about the current method of bid award procedure and other alternatives. The conclusions are drawn based on the assessment made on status of the projects. Primarily progress made in most of the projects is behind as planned schedule. This could be due to schedule delays resulting because of unavailability of material, any socio-political disturbance in progress of work and other unavoidable delay. Secondly, lack of funds is due to inflation and improper fixation of allowance for escalation. Henceforth it can be recommended to consider competitive lowest bidding. In this process all the bidders should be rated on the basis of their technical experience, cost of previous works done and after that award should be made to one of the bidders in pool of lowest bid with sufficient rating points.

\section{References}

[1] Doloi, H., Sawhney, A., Iyer, K.C. and Rentala, S. (2012) Analysing Factors Affecting Delays in Indian Construction Projects. International Journal of Project Management, 30, 479-489. https://doi.org/10.1016/j.ijproman.2011.10.004

[2] Doloi, H. (2008) Analysing the Novated Design and Construct Contract from the Client's, Design Team's and Contractor's Perspectives. Construction Management and Economics, 26, 1181-1196. https://doi.org/10.1080/01446190802512359

[3] Doloi, H. (2009) Analysis of Pre-Qualification Criteria in Contractor Selection and Their Impacts on Project Success. Construction Management and Economics, 27, 1245-1263. https://doi.org/10.1080/01446190903394541

[4] Uher, T.E. and Runeson, G. (1984) Pre-Tender and Post Tender Negotiations in Australia. Construction Management and Economics, 2, 185-192. https://doi.org/10.1080/01446198400000017

[5] Holt, G.D., Olomolaiye, P.O. and Harris, F.C. (1995) A Review of Contractor Selection Practice in the UK Construction Industry. Building and Environment, 30, 553-561. 
https://doi.org/10.1016/0360-1323(95)00008-T

[6] Russell, J.S., Hancher, D.E. and Skibiewski, M.J. (1992) Contractor Prequalification Data for Construction Owners. Construction Management and Economics, 10, 117-135. https://doi.org/10.1080/01446199200000012

[7] Hatush, Z. and Skitmore, M. (1997) Evaluating Contractor Prequalification Data: Selection Criteria and Project Success Factors. Construction Management and Economics, 15, 129-147. https://doi.org/10.1080/01446199700000002

[8] Pongpeng, J. and Liston, J. (2003) TebSeM: A Multicriteria and Multidecision Makers' Model in Tender Evaluation. Construction Management and Economics, 21, 21-30. https://doi.org/10.1080/0144619032000065090

[9] Lam, K.C., Palaneeswaran, E. and Yu, C. (2009) A Support Vector Machine Model for Contractor Prequalification. Automation in Construction, 18, 321-329. https://doi.org/10.1016/j.autcon.2008.09.007

[10] Holt, G.D. (1998) Which Contractor Selection Methodology? International Journal of Project Management, 16, 153-164. https://doi.org/10.1016/S0263-7863(97)00035-5

[11] Ng, S.T. and Luu, C.D.T. (2008) Modelling Subcontractor Registration Decisions through Case-Based Reasoning Approach. Automation in Construction, 17, 873-881. https://doi.org/10.1016/j.autcon.2008.02.015

[12] Raisbeck, P. (2008) Perceptions of Architectural Design and Project Risk: Understanding the Architects' Role in a PPP Project. Construction Management and Economics, 26, 1145-1157. https://doi.org/10.1080/01446190802512342

[13] Aibinu, A. and Pasco, T. (2008) The Accuracy of Pre-Tender Building Cost Estimates in Australia. Construction Management and Economics, 26, 1257-1269. https://doi.org/10.1080/01446190802527514

[14] Akintoye, A., Hardcastle, C., Beck, M. and Chinyo, E. (2003) Achieving Best Value in Private Finance Initiative Project Procurement. Construction Management and Economics, 21, 461-470. https://doi.org/10.1080/0144619032000087285

[15] Alarcon, L.F. and Mourgues, C. (2002) Performance Modeling for Contractor Selection. Journal of Management in Engineering, 18, 52-60. https://doi.org/10.1061/(ASCE)0742-597X(2002)18:2(52)

[16] Chan, D.W.M. and Kumaraswamy, M.M. (1997) A Comparative Study of Causes of Time Overruns in Hong Kong Construction Projects. International Journal of Project Management, 15, 55-63. https://doi.org/10.1016/S0263-7863(96)00039-7

[17] Cheng, E.W.L. and Li, H. (2004) Contractor Selection Using the Analytic Network Process. Construction Management and Economics, 22, 1021-1032. https://doi.org/10.1080/0144619042000202852

[18] Ward, S.C., Curtis, B. and Chapman, C.B. (1991) Objectives and Performance in Construction Projects. Construction Management and Economics, 9, 343-353. https://doi.org/10.1080/01446199100000027

[19] Wegelius-Lehtonen, T. (2001) Performance Measurement in Construction Logistics. International Journal of Production Economics, 69, 107-116. https://doi.org/10.1016/S0925-5273(00)00034-7

[20] Singh, A. (2016) Textbook on Law of Contract and Specific Relief. Eastern Book Company. New Delhi, 488.

[21] Welling, D.T. and Kamann, D.J.F. (2001) Vertical Cooperation in the Construction Industry: Size Does Matter. Journal of Supply Chain Management, 37, 28-33. https://doi.org/10.1111/j.1745-493X.2001.tb00110.x

[22] Winkler, R.L. (1990) Decision Modeling and Rational Choice: AHP and Utility Theory. 
Management Science, 36, 247-248. https://doi.org/10.1287/mnsc.36.3.247

[23] Wood, G.D. and Ellis, R.C.T. (2005) Main Contractor Experiences of Partnering Relationships on UK Construction Projects. Construction Management and Economics, 23, 317-325. https://doi.org/10.1080/0144619042000287714

[24] Griffith, A. and King, A. (2004) Examining the Dynamics of Novation from the Principal Contractors' and Architects' Perspectives. Australian Journal of Construction Economics and Building, 3, 13-18. https://doi.org/10.5130/ajceb.v3i1.2907

[25] Howden, R. and Billard, R. (1992) The Use of Novation Contracts in Building Delivery. Royal Australian Institute of Architects, Canberra.

[26] Iyer, K.C. and Jha, K.N. (2005) Factors Affecting Cost Performance: Evidence from the Indian Construction Projects. International Journal of Project Management, 23, 283-295. https://doi.org/10.1016/j.ijproman.2004.10.003

[27] Ishii, N., Takano, Y. and Muraki, M. (2011) A Bidding Price Decision Process in Consideration of Cost Estimation Accuracy and Deficit Order Probability for Engineer-to-Order Manufacturing. Technical Report No. 2011-1, Tokyo.

[28] Helmus, F.P. (2008) Process Plant Design: Project Management from Inquiry to Acceptance. Wiley, Weinheim. https://doi.org/10.1002/9783527621569

Submit or recommend next manuscript to SCIRP and we will provide best service for you:

Accepting pre-submission inquiries through Email, Facebook, LinkedIn, Twitter, etc.

A wide selection of journals (inclusive of 9 subjects, more than 200 journals)

Providing 24-hour high-quality service

User-friendly online submission system

Fair and swift peer-review system

Efficient typesetting and proofreading procedure

Display of the result of downloads and visits, as well as the number of cited articles

Maximum dissemination of your research work

Submit your manuscript at: http://papersubmission.scirp.org/

Or contact ojbm@scirp.org 